University of Nebraska - Lincoln

DigitalCommons@University of Nebraska - Lincoln

2010

\title{
Effects of Co-Products and Breed of Sire on the Performance, Carcass Characteristics, and Rates of Ultrasound Backfat and Marbling Deposition in Feedlot Cattle
}

C. O. Trejo

University of Illinois, Urbana

D. B. Faulkner

University of Illinois, Urbana, dfaulkner@email.arizona.edu

A. Shreck

University of Illinois, Urbana

J. W. Homm

Elanco Animal Health, Eli Lilly and Company, Greenfield, IN

T. G. Nash

University of Illinois, Urbana

See next page for additional authors

Follow this and additional works at: https://digitalcommons.unl.edu/animalscifacpub

Part of the Animal Sciences Commons

Trejo, C. O.; Faulkner, D. B.; Shreck, A.; Homm, J. W.; Nash, T. G.; Rodriguez-Zas, S. L.; and Berger, L. L., "Effects of Co-Products and Breed of Sire on the Performance, Carcass Characteristics, and Rates of Ultrasound Backfat and Marbling Deposition in Feedlot Cattle" (2010). Faculty Papers and Publications in Animal Science. 781.

https://digitalcommons.unl.edu/animalscifacpub/781

This Article is brought to you for free and open access by the Animal Science Department at DigitalCommons@University of Nebraska - Lincoln. It has been accepted for inclusion in Faculty Papers and Publications in Animal Science by an authorized administrator of DigitalCommons@University of Nebraska - Lincoln. 


\section{Authors}

C. O. Trejo, D. B. Faulkner, A. Shreck, J. W. Homm, T. G. Nash, S. L. Rodriguez-Zas, and L. L. Berger 

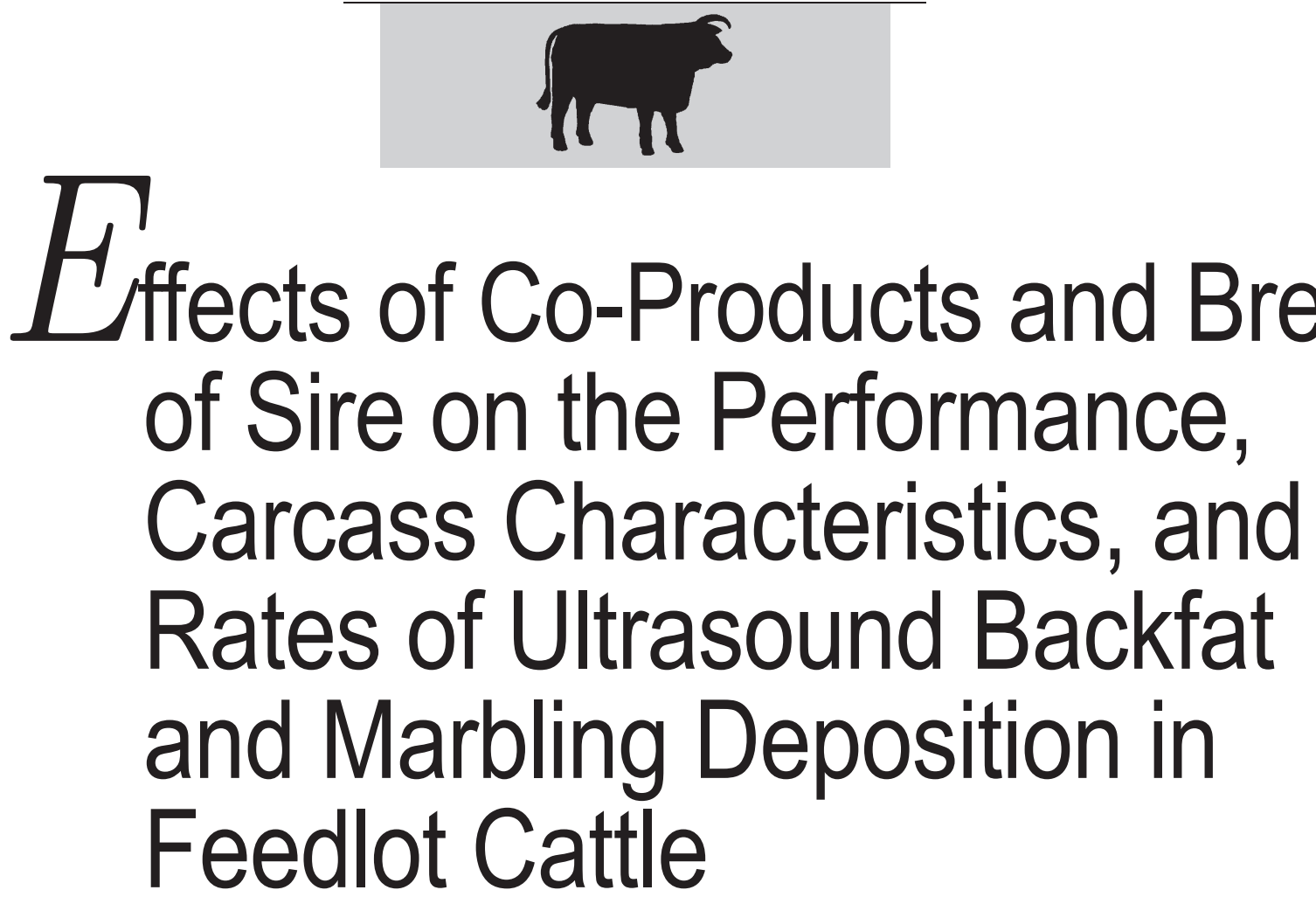

\author{
C. O. Trejo, ${ }^{* 1}$ D. B. Faulkner, ${ }^{*}$ PAS, A. Shreck, ${ }^{*}$ J. W. Homm,† T. G. Nash, \\ S. L. Rodriguez-Zas, ${ }^{*}$ and L. L. Berger, $\ddagger$ PAS \\ *Department of Animal Sciences, University of Illinois, Urbana 61801; \\ †Elanco Animal Health, Eli Lilly and Company, Greenfield, IN 46140; \\ ‡Department of Animal Sciences, University of Nebraska, Lincoln 68583
}

\section{ABSTRACT}

Recently, high prices have driven producers to replace corn partially or totally with more affordable ingredients. A total of 1,256 DNA-validated progeny from Angus $(n=241)$, Simmental $(n=599)$, Simmental $\times$ Angus $(S A ; n=296)$, and $75 \%$ Simmental (75S; $n=120)$ sires were used to evaluate the effects of feedlot nutrition and sire breed on the performance, carcass characteristics, and rates of ultrasound backfat and marbling deposition in feedlot cattle. Diets included corn or a corn co-product: dried distillers grains with solubles (DDGS), fresh wet distillers grains, wet corn gluten feed, stored wet distillers grains, or dried corn gluten feed. Dry matter intake for steers fed the co-product diets increased by approximately $8 \%$ compared with that

${ }^{1}$ Corresponding author: cotrejo2@illinois. edu of steers fed the high-corn diet. Steers fed the corn co-product diets had greater $(P<0.05) A D G$. Steers fed DDGS, wet distillers grains, and wet or dried corn gluten feed deposited approximately 0.02 $\mathrm{mm} / \mathrm{d}$ more $(P<0.05)$ backfat than steers fed the high-corn diet. The greatest $(P<0.05)$ rate of intramuscular fat deposition was in steers fed $40 \%$ DDGS. Steers sired by Angus bulls had greater $(P<0.05)$ DMI than the progeny of Simmental and SA sires. Backfat was greater $(P<0.05)$ in the progeny of Angus bulls than in the progeny of Simmental, SA, and $75 S$ sires. Steers sired by Angus bulls had the greatest $(P<$ $0.05)$ marbling score. The greatest rate $(P<0.05)$ of backfat deposition was observed in the progeny of Angus sires. Steers sired by Angus and SA bulls had the greatest rates $(P<0.05)$ of marbling deposition. The progeny of Simmental, Angus, and $75 S$ were similar $(P>0.05)$ in the amount of marbling deposited per centimeter of backfat (184 marbling score units (cm of backfat). This study indicates that co-product diets had less effect on performance and carcass quality than did breed of sire.

Key words: breed, co-product, sire, ultrasound backfat deposition, ultrasound marbling deposition

\section{INTRODUCTION}

Since the publication of USDA standards for beef carcass quality in 1928, the US cattle industry has had a system of grades to classify beef products. Over the years, modifications and additions have been implemented to update and improve the applications of those standards. However, these carcass characteristics (i.e., marbling, lean texture and color, and physiological age) have controlled the quality grading standards. Specifically, marbling and muscle characteristics (i.e., maturity, firmness, texture, 
and color) largely determine QG. Feedlot diets have traditionally included large amounts of corn. However, recent high prices have encouraged producers to replace corn partially or totally with a more affordable ingredient or ingredients. The supply of distillers grains has increased rapidly in the past $3 \mathrm{yr}$, making it a viable corn replacement.

Crossbreeding systems have been developed to exploit heterosis and breed complementarity. The differences between the breeds used, as well as the differences in individual sires used, contribute to variation in the progeny (Greiner, 2002). Diverse breeds are required to exploit heterosis and to match genetic potential with diverse markets, feed resources, and climates (Cundiff et al., 1993). Sire selection must maintain reasonable uniformity from one generation to the next while taking advantage of the strengths of various breeds used in the system. The objective of this study was to determine the effect of corn co-product diets and Simmental, Angus, and Simmental $\times$ Angus (SA) sire breeds on performance, carcass characteristics, and rates of ultrasound backfat and marbling deposition of finishing steers.

\section{MATERIALS AND METHODS}

\section{Animals and Management}

A total of 1,256 steers from identified Angus ( $\mathrm{n}=11)$, Simmental ( $\mathrm{n}=$ $32)$, SA $(n=18)$, and $75 \%$ Simmental $(75 \mathrm{~S} ; \mathrm{n}=4)$ sires were used across 3 different years from 3 separate ranches. The same ranches were used each year. Individual blood samples $(10 \mathrm{~mL})$ were sent to a laboratory of the University of Illinois for parental validation. Confirmation of sire paternity was assessed by genotyping of 15 microsatellite markers, including 8 of the 9 markers recommended by the International Society for Animal Genetics Standing Committee on Cattle Molecular Markers and Parentage Testing (Sherman et al., 2004). Parentage exclusion analysis was con- ducted using the computer program Cervus (Slate et al., 2000).

Sixty-five sires from AI studs were randomly assigned to Angus or Angus crossbred cow herds. All sire breeds were represented on each ranch. In addition, 14 sires (Simmental, SA, and Angus) were used in more than 1 yr. Animals used in this trial were managed according to the guidelines recommended in the Guide for the Care and Use of Agricultural Animals in Agricultural Research and Teaching (Consortium, 1988). Experimental protocols were submitted to and approved by the University of Illinois Institutional Animal Care and Use Committee. Before being shipped to the University of Illinois, steers were vaccinated for bovine respiratory syncytial virus, infectious bovine rhinotracheitis virus, bovine viral diarrhea virus, parainfluenza 3 virus, and Pasteurella. The implant strategy used during the first and third years was implantation with Component TE-IS (80 mg trenbolone acetate, 16 mg estradiol, $29 \mathrm{mg}$ tylosin tartrate; VetLife, Overland Park, KS) at the initiation of the trial and reimplantation with Component TE-S (120 mg trenbolone acetate, $24 \mathrm{mg}$ estradiol, $29 \mathrm{mg}$ tylosin tartrate; VetLife) after $84 \mathrm{~d}$ on feed. In yr 2, steers were implanted with Revalor-G (40 mg trenbolone acetate and $8 \mathrm{mg}$ estradiol; Intervet, Millsboro, DE) at the initiation of the trial and reimplanted with Component TE-S (120 mg trenbolone acetate, $24 \mathrm{mg}$ estradiol, $29 \mathrm{mg}$ tylosin tartrate; VetLife) after $84 \mathrm{~d}$ on feed. Animals were randomly assigned to a dietary treatment by breed of sire across the $3 \mathrm{yr}$. Each dietary treatment had a representation of all sire breeds. A total of 12 diets (Tables 1 and 2) were represented in the compiled data. Dietary treatments were as follows: 1) $75 \%$ dry-rolled corn; 2) 50\% dry-rolled corn; 3) 40\% dried distillers grains with solubles; 4) $40 \%$ fresh wet distillers grains); 5) $40 \%$ fresh wet corn gluten feed; 6 ) $40 \%$ stored wet distillers grains; 7 ) $20 \%$ wet distillers grains $+20 \%$ wet corn gluten feed; 8) 40\% stored wet distillers grains $+7 \%$ dry rolled corn;
9) $40 \%$ stored wet distillers grains + $7.5 \%$ hay; 10) $40 \%$ wet corn gluten feed; 11) $20 \%$ fresh wet distillers grains $+20 \%$ wet corn gluten feed; and 12) $40 \%$ dried corn gluten feed.

Diets 1 to 4 were replicated during the 3 yr. Diet 9 was replicated during the first and third year. All other diets were offered during a particular year. Diets were formulated to meet or exceed the minimum NRC (1996) requirements for maintenance and BW gain.

\section{Performance and Ultrasound Data Collection}

To evaluate live animal performance, steer BW, hip height, and ultrasonic measurements of backfat thickness and marbling were recorded every $28 \mathrm{~d}$ for yr 1 and every $42 \mathrm{~d}$ for yr 2 and 3 throughout the feeding period. Ultrasound measurements were taken with an Aloka 500V B-mode instrument (Aloka, Wallingford, CT) equipped with a $3.5-\mathrm{MHz}$ generalpurpose transducer array. Backfat thickness and marbling measurements were taken in a transverse orientation between the 12th and 13th ribs approximately $10 \mathrm{~cm}$ distal from the midline. Marbling image analysis was performed according to the method of Brethour (1994). Daily feed intake was recorded using the GrowSafe automated feeding system (GrowSafe Systems Ltd., Airdrie, Alberta, Canada). Final individual-animal ADG and feed efficiency were calculated based on carcass adjusted final weights. Adjusted final weight was calculated by dividing hot carcass weight (HCW) by the average dressing percentage of the slaughter group. Steers were slaughtered in 3 groups for yr 1 and 2 and in 2 groups for yr 3. Slaughter groups in all years were sorted based on ultrasound backfat thickness and BW. Steers had a minimum of 8.89 $\mathrm{mm}$ of backfat and $545.5 \mathrm{~kg}$ of BW. For yr 1, groups were slaughtered after 121,147 , and $168 \mathrm{~d}$ on feed (80, 194, and 175 animals, respectively). For yr 2, groups were slaughtered after 146, 169, and $195 \mathrm{~d}$ on feed (27, 202, and 206 animals, respectively). 
Table 1. Ingredient composition of dietary treatments

Dietary treatment ${ }^{2}$

\begin{tabular}{|c|c|c|c|c|c|c|c|c|c|c|c|c|}
\hline Ingredient, ${ }^{1} \%$ & Cn & $50 \mathrm{C}$ & 40DG & 40WD & 40WC & 40SD & 20WD & 40DG/C & 40DG/H & 40WCG & 20WD/WCG & 40DCGF \\
\hline Dry-rolled corn & 75 & 50 & - & - & - & - & - & 7 & - & - & 35 & 35 \\
\hline DDGS & - & 25 & 40 & - & - & - & - & 40 & - & - & - & - \\
\hline FWDG & - & - & - & 40 & - & - & 20 & - & - & - & 20 & - \\
\hline SWDG & - & - & - & - & - & 40 & - & - & 40 & - & - & - \\
\hline FWCGF & - & - & - & - & 40 & - & - & - & - & - & - & - \\
\hline WCGF & - & - & - & - & - & - & 20 & - & - & 40 & 20 & - \\
\hline DCGF & - & - & - & - & - & - & - & - & - & - & - & 40 \\
\hline Soyhulls & - & - & 35 & 35 & 35 & 35 & 35 & 35 & 35 & 35 & - & - \\
\hline Corn silage & 15 & 15 & 15 & 15 & 15 & 15 & 15 & 8 & 7.5 & 15 & 15 & 15 \\
\hline Hay & - & - & - & - & - & - & - & - & 7.5 & - & - & - \\
\hline Soy-based supplement & 10 & - & - & - & - & - & - & - & - & - & - & - \\
\hline Co-product supplement & - & 10 & 10 & 10 & 10 & 10 & 10 & 10 & 10 & 10 & 10 & 10 \\
\hline
\end{tabular}

${ }^{1}$ DDGS = dried distillers grains with solubles; FWDG = fresh wet distillers grains; SWDG = stored wet distillers grains; FWCGF = fresh wet corn gluten feed; WCGF = wet corn gluten feed; DCGF = dried corn gluten feed.

${ }^{2} \mathrm{Cn}=75 \%$ dry-rolled corn; $50 \mathrm{C}=50 \%$ dry-rolled corn; $40 \mathrm{DG}=40 \%$ dry distillers grains; $40 \mathrm{WD}=40 \%$ fresh wet distillers grains; 40WC $=40 \%$ fresh wet corn gluten feed; $40 \mathrm{SD}=40 \%$ stored wet distiller grains; $20 \mathrm{WD}=20 \%$ wet distillers grains $+20 \%$ wet corn gluten feed; $40 \mathrm{DG} / \mathrm{C}=40 \%$ stored wet distillers grains $+7 \%$ dry-rolled corn; $40 \mathrm{DG} / \mathrm{H}=40 \%$ stored wet distillers grains $+7.5 \%$ hay; $40 \mathrm{WCG}=40 \%$ wet corn gluten feed; $20 \mathrm{WD} / \mathrm{WCG}=20 \%$ fresh wet distillers grains $+20 \%$ wet corn gluten feed; $40 \mathrm{DCGF}=40 \%$ dried corn gluten feed.

Table 2. Nutrient composition of dietary treatments

Dietary treatment ${ }^{1}$

\begin{tabular}{|c|c|c|c|c|c|c|c|c|c|c|c|c|}
\hline Item & Cn & $50 \mathrm{C}$ & 40DG & 40WD & 40WC & 40SD & 20WD & 40DG/C & 40DG/H & 40WCG & 20WD/WCG & 40DCGF \\
\hline DM, \% & 71 & 73 & 71 & 54 & 56 & 48 & 53 & 79 & 49 & 56 & 55 & 74 \\
\hline $\mathrm{CP}, \%$ & 13.2 & 14.6 & 18.0 & 18.1 & 14.5 & 19.0 & 17.9 & 20.0 & 21.4 & 13.8 & 17.4 & 14.3 \\
\hline ADF, $\%$ & 7.1 & 7.3 & 23.1 & 24.0 & 23.9 & 20.5 & 22.3 & 19.8 & 25.6 & 9.0 & 23.3 & 23.3 \\
\hline NDF, $\%$ & 14.7 & 17.3 & 38.7 & 40.8 & 43.0 & 43.4 & 40.4 & 33.8 & 45.1 & 23.6 & 38.9 & 40.1 \\
\hline TDN, \% & 77 & 76 & 68 & 67 & 68 & 67 & 68 & 68 & 66 & 74 & 68 & 68 \\
\hline $\mathrm{NE}_{\mathrm{m}}, \mathrm{Mcal} / \mathrm{lb}$ & 0.86 & 0.84 & 0.71 & 0.70 & 0.71 & 0.70 & 0.71 & 0.73 & 0.68 & 0.82 & 0.71 & 0.71 \\
\hline $\mathrm{NE}_{\mathrm{q}}^{\mathrm{m}}, \mathrm{Mcal} / \mathrm{lb}$ & 0.57 & 0.56 & 0.44 & 0.43 & 0.44 & 0.43 & 0.44 & 0.46 & 0.41 & 0.54 & 0.44 & 0.44 \\
\hline $\mathrm{Ca}, \%$ & 0.40 & 0.55 & 0.66 & 0.66 & 0.61 & 0.81 & 0.60 & 0.61 & 0.88 & 0.59 & 0.65 & 0.70 \\
\hline $\mathrm{P}, \%$ & 0.35 & 0.46 & 0.47 & 0.46 & 0.45 & 0.45 & 0.44 & 0.49 & 0.38 & 0.50 & 0.49 & 0.39 \\
\hline $\mathrm{Mg}, \%$ & 0.13 & 0.19 & 0.25 & 0.27 & 0.28 & 0.29 & 0.24 & 0.23 & 0.26 & 0.23 & 0.27 & 0.26 \\
\hline $\mathrm{K}, \%$ & 0.60 & 0.67 & 1.09 & 1.08 & 1.12 & 1.18 & 0.96 & 0.91 & 1.21 & 0.78 & 1.06 & 0.97 \\
\hline $\mathrm{Na}, \%$ & 0.11 & 0.17 & 0.22 & 0.25 & 0.18 & 0.32 & 0.24 & 0.36 & 0.27 & 0.16 & 0.28 & 0.22 \\
\hline I, ppm & 84 & 128 & 244 & 299 & 348 & 356 & 277 & 257 & 359 & 174 & 243 & 447 \\
\hline $\mathrm{Zn}, \mathrm{ppm}$ & 48 & 68 & 70 & 73 & 75 & 83 & 77 & 73 & 73 & 73 & 69 & 55 \\
\hline $\mathrm{Cu}, \mathrm{ppm}$ & 15 & 24 & 21 & 23 & 21 & 26 & 23 & 24 & 26 & 21 & 20 & 15 \\
\hline $\mathrm{Mn}, \mathrm{ppm}$ & 16 & 21 & 23 & 25 & 24 & 31 & 24 & 22 & 30 & 21 & 22 & 26 \\
\hline $\mathrm{Mb}, \mathrm{ppm}$ & 0.33 & 0.40 & 0.42 & 0.50 & 0.57 & 0.60 & 0.47 & 0.53 & 0.70 & 0.40 & 0.50 & 0.40 \\
\hline
\end{tabular}

${ }^{1} \mathrm{Cn}=75 \%$ dry-rolled corn; 50C $=50 \%$ dry-rolled corn; 40DG $=40 \%$ dry distillers grains; $40 \mathrm{WD}=40 \%$ fresh wet distillers grains; $40 \mathrm{WC}=40 \%$ fresh wet corn gluten feed; $40 \mathrm{SD}=40 \%$ stored wet distiller grains; $20 \mathrm{WD}=20 \%$ wet distillers grains $+20 \%$ wet corn gluten feed; $40 \mathrm{DG} / \mathrm{C}=40 \%$ stored wet distillers grains $+7 \%$ dry-rolled corn; $40 \mathrm{DG} / \mathrm{H}=40 \%$ stored wet distillers grains $+7.5 \%$ hay; 40WCG $=40 \%$ wet corn gluten feed; $20 \mathrm{WD} / \mathrm{WCG}=20 \%$ fresh wet distillers grains $+20 \%$ wet corn gluten feed; $40 \mathrm{DCGF}=40 \%$ dried corn gluten feed. 
Groups for yr 3 were slaughtered after 145 and $170 \mathrm{~d}$ on feed (154 and 321 animals, respectively). Differences in days on feeds among the slaughter groups were based on the ability of the animals to reach the minimum requirements of ultrasound backfat thickness and BW.

\section{Carcass Data Collection}

Steers were slaughtered at a commercial processing facility. Animals were stunned via captive bolt pistol and exsanguinated. On the day of slaughter, individual carcass measurements were taken for $\mathrm{HCW}$ and liver score. After undergoing a 24-h chill at $-4^{\circ} \mathrm{C}$, measurements for backfat thickness, KPH percentage, and marbling were collected by trained university personnel. Chromatography paper was used to take an image of the longissimus dorsi, and measurements for the ribeye area (REA) were recorded using a planometer. University of Illinois measurements were used to determine $\mathrm{QG}$ and calculated YG (CYG). Yield grade was calculated using the equation [2.5 $+(2.5 \times$ in. of backfat thickness $)+$ $(0.20 \times \mathrm{KPH} \%)+(0.0038 \times \mathrm{lb}$ of $\mathrm{HCW})-\left(0.32 \times\right.$ in. $^{2}$ of longissimus dorsi muscle)] (Taylor, 1994). Quality grade and YG determined by USDA were used for comparison with the university observations.

\section{Statistical Analyses}

The individual animal was used as the experimental unit for live animal performance, carcass, and ultrasound parameters. Data were analyzed using the MIXED procedure of SAS (SAS Institute, 2003). Fixed effects in the model included diet, breed of sire, year, and ranch. The random effects in the model were pen and sire nested within breed of sire. Interactions among fixed effects were analyzed, but only results for significant interactions are discussed. To account for unequal replication within treatments and its effect on the degrees of freedom, the Kenward-Roger method was used for the adjustment. A simple linear regression model using the REG procedure of SAS was used to obtain a slope and intercept for each experimental unit for rates of backfat deposition and marbling over days on feed, and rates of marbling over backfat deposition. Main effect means for all analyses were separated using the LSD procedure of SAS when the respective $F$-tests were significant $(P$ $\leq 0.05)$.

\section{RESULTS AND DISCUSSION}

\section{Dietary Treatment Effect}

Performance. Initial BW did not differ $(P>0.70$; Table 3$)$ among dietary treatments. However, adjusted final weight differed significantly among diets. When compared with the high-corn diet, steers fed the coproduct diets were heavier $(P<0.05)$, excluding the diets fresh wet distillers grains and wet corn gluten feed. Steers fed co-products had a $21-\mathrm{kg}$ greater adjusted final weight than steers fed the high-corn diet. Furthermore, steers fed diets with $40 \%$ stored wet distillers grains or distillers dried grains with solubles (DDGS) had the greatest adjusted final weight. Similarly, steers fed fresh wet distillers grains or dried distillers grains diets had higher adjusted final weights than those fed diets with wet or dried corn gluten feed. In agreement with the previous results, Loza et al. (2005) reported a quadratic increase $(P<$ 0.01 ) in carcass adjusted final weight as wet distillers grains inclusion increased to a $50 \%$ level. Previously, Al-Suwaiegh et al. (2002) observed a $17-\mathrm{kg}$ difference in the adjusted final weight of finishing yearling steers when fed wet corn distillers grains compared with those fed a traditional high-corn feedlot diet.

An increase $(P<0.0001)$ in DMI was detected among steers fed coproduct-containing diets. Dry matter intake for steers fed the co-product diets increased by approximately $8 \%$ $(0.88 \mathrm{~kg})$ compared with that of steers fed the high-corn diet; however, the intakes for steers fed the $50 \%$ dryrolled corn and $40 \%$ wet corn gluten feed diets were not different $(P>$ 0.05 ) compared with those fed the high-corn diet. In contrast, previous studies (Lodge et al., 1997; Al-Suwaiegh et al., 2002; Loy et al., 2007) have found similar DMI for steers fed distillers grains diets when compared with a corn-based control diet. However, Loza et al. (2005) reported that steers fed diets containing 25 or $50 \%$ co-product had greater DMI than steers fed the control diet.

Average daily gain for all dietary treatments was approximately 1.57 $\mathrm{kg} / \mathrm{d}$. Steers fed the corn co-product diets had higher $(P<0.05)$ daily BW gains than those fed the high-corn diet. With the exception of steers fed dried corn gluten feed, the average difference in BW gain was approximately $0.14 \mathrm{~kg} / \mathrm{d}$ more than that of steers fed the high-corn diet. Steers fed diets containing $40 \%$ wet or dried distillers grains gained approximately $0.10 \mathrm{~kg} / \mathrm{d}$ more than steers fed 20 or $25 \%$ wet or dried distillers grains.

Feed efficiency was analyzed as G:F, in which differences $(P<$ $0.0001)$ were detected among dietary treatments. The least efficiency was observed for steers fed $40 \%$ dried corn gluten feed, gaining $13 \%$ less $(P$ $<0.0001)$ per unit of feed compared with steers fed the high-corn diet. Moreover, steers fed $40 \%$ stored wet distillers grains and $40 \%$ stored wet corn gluten feed were $6 \%$ more efficient $(P<0.05)$ than steers fed the high-corn ration and had the highest G:F ratios. In agreement with our findings, Ham et al. (1994) and Lodge et al. (1997) reported that cattle fed the wet or dry distillers by-product gained faster and more efficiently than cattle fed the dry-rolled corn control diet. Furthermore, cattle fed wet distillers by-products had similar BW gains, consumed less feed, and were more efficient than cattle fed DDGS. Similar results were reported by Larson et al. (1993) in finishing calves and yearlings. In contrast, Leibovich et al. (2009) reported less daily BW gain and reduced G:F in finishing steers fed sorghum wet distillers grains with dry-rolled corn. 
Table 3. Dietary treatment effect on performance characteristics of feedlot steers

\begin{tabular}{|c|c|c|c|c|c|}
\hline Item & Initial BW, kg & Adjusted final BW, ${ }^{1} \mathrm{~kg}$ & DMI, ${ }^{2} \mathbf{k g}$ & ADG, kg & G:F \\
\hline \multicolumn{6}{|c|}{ Dietary treatment ${ }^{3}$} \\
\hline $\mathrm{Cn}$ & 339 & $579^{*}$ & $9.70^{*}$ & $1.46^{*}$ & $0.152^{*}$ \\
\hline $50 \mathrm{C}$ & 334 & 592 & $9.85^{\star}$ & $1.56^{*}$ & 0.159 \\
\hline 40DG & 335 & 614 & $11.05^{*}$ & 1.68 & $0.153^{*}$ \\
\hline 40WD & 334 & $598^{*}$ & $10.21^{*}$ & $1.59^{*}$ & $0.157^{*}$ \\
\hline 40WC & 335 & $588^{*}$ & $10.84^{*}$ & $1.53^{*}$ & $0.143^{*}$ \\
\hline 40SD & 334 & 609 & $10.17^{*}$ & 1.64 & 0.163 \\
\hline 20WD & 331 & 600 & $10.78^{*}$ & 1.62 & $0.151^{*}$ \\
\hline 40DG/C & 334 & 601 & $10.65^{*}$ & $1.60^{*}$ & $0.152^{*}$ \\
\hline 40DG/H & 332 & 606 & $10.18^{*}$ & 1.64 & 0.162 \\
\hline 40WCG & 336 & $590^{*}$ & $9.55^{*}$ & $1.55^{\star}$ & 0.162 \\
\hline 20WD/WCG & 334 & 600 & $10.35^{*}$ & 1.62 & 0.158 \\
\hline 40DCGF & 341 & $589^{*}$ & 11.78 & $1.50^{*}$ & $0.132^{*}$ \\
\hline SEM & 3 & 9 & 0.35 & 0.05 & 0.008 \\
\hline$P$-value & 0.6960 & $<0.0001$ & $<0.0001$ & $<0.0001$ & $<0.0001$ \\
\hline
\end{tabular}

${ }^{1}$ Calculated from hot carcass weight divided by a pooled dressing percentage.

${ }^{2}$ Average daily DMI.

${ }^{3} \mathrm{Cn}=75 \%$ dry-rolled corn; $50 \mathrm{C}=50 \%$ dry-rolled corn; $40 \mathrm{DG}=40 \%$ dry distillers grains; $40 \mathrm{WD}=40 \%$ fresh wet distillers grains; $40 \mathrm{WC}=40 \%$ fresh wet corn gluten feed; $40 \mathrm{SD}=40 \%$ stored wet distiller grains; $20 \mathrm{WD}=20 \%$ wet distillers grains $+20 \%$ wet corn gluten feed; $40 \mathrm{DG} / \mathrm{C}=40 \%$ stored wet distillers grains $+7 \%$ dry-rolled corn; $40 \mathrm{DG} / \mathrm{H}=40 \%$ stored wet distillers grains $+7.5 \%$ hay; $40 \mathrm{WCG}=40 \%$ wet corn gluten feed; $20 \mathrm{WD} / \mathrm{WCG}=20 \%$ fresh wet distillers grains $+20 \%$ wet corn gluten feed; $40 \mathrm{DCGF}=40 \%$ dried corn gluten feed.

*Significant differences $(P<0.05)$ when compared with the highest value within the same performance characteristic measurement.

Differences in environmental patterns across years can influence the performance of animals. A significant $(P<0.05)$ year $\times$ dietary treatment interaction was detected for the performance characteristics of DMI, G:F, and ADG. Furthermore, a significant $(P<0.05)$ year $\times$ ranch interaction for the same performance characteristics could explain the differences in performance outcomes across the $3 \mathrm{yr}$. In this study, new diets with differences in nutrient composition were included across years. However, diets were formulated to meet or exceed the NRC (1996) recommendations for beef cattle. Furthermore, Mader (2003) concluded that beef cattle are traditionally managed outdoors with exposure to natural and variable environmental conditions. Cattle are particularly vulnerable not only to extreme environmental conditions, but also to rapid changes in these conditions.

Carcass. Carcass characteristic measurements for marbling score, $\mathrm{REA}$, and percentage of $\mathrm{KPH}$ were similar $(P>0.05$; Table 4$)$ across dietary treatments. Carcass QG averaged low Choice (marbling score $=$ 551). The measurements for REA and $\mathrm{KPH}$ averaged $91.04 \mathrm{~cm}^{2}$ and $2.27 \%$, respectively.

Steers fed the high-corn diet had the lightest carcass $(P<0.05)$ weights when compared with the HCW from steers fed the other diets. Carcasses of steers fed DDGS and WDG (stored and fresh) weighed approximately 16 $\mathrm{kg}$ more than carcasses of steers fed the high-corn diet. However, no difference $(P>0.05)$ was detected between the $\mathrm{HCW}$ of steers fed the high-corn diet and CGF (wet or dried). Similarly, Vander Pol et al. (2006a) found a difference of approximately $15 \mathrm{~kg}$ in HCW between steers fed a diet with $30 \%$ wet distillers grains and those fed a control diet that had high moisture and dry-rolled corn. In addition, Al-Suwaiegh et al. (2002) reported heavier carcasses for steers fed wet distillers grain diets compared with those fed a corn-based diet.
Backfat measurements for steers fed all diets averaged $1.26 \mathrm{~cm}$. Steers offered the diet with 40\% DDGS had the greatest backfat deposition. Furthermore, no differences $(P>0.05)$ were detected when compared with the other diets containing DDGS or wet distillers grains. Steers fed corn gluten feed (diets 10 to 12 ) had the least backfat deposition. However, no difference $(P>0.05)$ was detected when compared with steers fed the high-corn diet. Steers fed corn gluten feed had $0.17 \mathrm{~cm}$ less backfat than steers fed DDGS or wet distillers grains (stored and fresh) diets. In agreement with the previous results for marbling score, backfat, and calculated YG, Ham et al. (1994) indicated that cattle fed wet and dried distillers by-products diets showed no differences in liver abscess score, YG, and QG. Similar results were reported by AlSuwaiegh et al. (2002) for these carcass characteristics in steers fed wet corn and sorghum distillers grains. Furthermore, Larson et al. (1993) and Lodge et al. (1997) reported that 
Table 4. Effects of dietary treatments in carcass characteristics of feedlot steers

\begin{tabular}{|c|c|c|c|c|c|c|}
\hline Item & $\mathrm{HCW},{ }^{1} \mathrm{~kg}$ & Backfat, cm & Marbling $^{2}$ & $\mathrm{REA},{ }^{3} \mathrm{~cm}^{2}$ & KPH, \% & Calculated YG \\
\hline \multicolumn{7}{|c|}{ Dietary treatment ${ }^{4}$} \\
\hline $\mathrm{Cn}$ & $371^{*}$ & $1.15^{*}$ & 563 & 89.43 & 2.25 & 2.76 \\
\hline $50 C$ & $381^{*}$ & $1.31^{*}$ & 567 & 89.77 & 2.28 & 2.98 \\
\hline $40 D G$ & 394 & 1.41 & 567 & 91.44 & 2.35 & 3.11 \\
\hline 40WD & $385^{*}$ & 1.29 & 551 & 92.79 & 2.28 & 2.86 \\
\hline 40WC & $384^{*}$ & $1.33^{*}$ & 545 & 90.93 & 2.29 & 2.94 \\
\hline $40 S D$ & 385 & $1.29^{*}$ & 560 & 92.13 & 2.27 & 2.83 \\
\hline 20WD & 386 & 1.28 & 569 & 91.43 & 2.30 & 2.94 \\
\hline 40DG/C & 391 & 1.29 & 543 & 91.65 & 2.32 & 2.92 \\
\hline 40DG/H & 389 & 1.32 & 541 & 90.32 & 2.35 & 2.99 \\
\hline 40WCG & $378^{*}$ & $1.19^{*}$ & 555 & 92.20 & 2.27 & 2.70 \\
\hline 20WD/WCG & 379 & 1.16 & 558 & 90.99 & 2.24 & 2.79 \\
\hline 40DCGF & $378^{*}$ & $1.07^{*}$ & 548 & 90.16 & 2.15 & 2.71 \\
\hline SEM & 6 & 0.08 & 14 & 2.79 & 0.14 & 0.09 \\
\hline$P$-value & $<0.0001$ & $<0.0001$ & 0.1554 & 0.3598 & 0.1195 & 0.0038 \\
\hline
\end{tabular}

${ }^{1}$ Hot carcass wt.

${ }^{2}$ University of Illinois marbling score: $500=$ Small $^{0}, 600=$ Modest $^{0}$.

${ }^{3}$ Ribeye area.

${ }^{4} \mathrm{Cn}=75 \%$ dry-rolled corn; $50 \mathrm{C}=50 \%$ dry-rolled corn; $40 \mathrm{DG}=40 \%$ dry distillers grains; $40 \mathrm{WD}=40 \%$ fresh wet distillers grains; 40WC $=40 \%$ fresh wet corn gluten feed; $40 \mathrm{SD}=40 \%$ stored wet distiller grains; $20 \mathrm{WD}=20 \%$ wet distillers grains $+20 \%$ wet corn gluten feed; $40 \mathrm{DG} / \mathrm{C}=40 \%$ stored wet distillers grains $+7 \%$ dry-rolled corn; $40 \mathrm{DG} / \mathrm{H}=40 \%$ stored wet distillers grains $+7.5 \%$ hay; $40 \mathrm{WCG}=40 \%$ wet corn gluten feed; $20 \mathrm{WD} / \mathrm{WCG}=20 \%$ fresh wet distillers grains $+20 \%$ wet corn gluten feed; $40 \mathrm{DCGF}=40 \%$ dried corn gluten feed.

*Significant differences $(P<0.05)$ when compared with the highest value within the same carcass characteristic measurement.

fat thickness and liver score were not affected by inclusion of wet distillers grains. However, Larson et al. (1993) observed that calves fed increasing levels of wet distillers grains graded higher than control calves (corn-based diet). In addition, Al-Suwaiegh et al. (2002) concluded that these changes in QG characteristics were most likely due to feeding the steers for a similar number of days rather than to slaughtering the steers at a constant body composition.

On average, the CYG was 2.88 for all steers. The highest value for CYG (3.11) was for steers fed 40\% DDGS. These steers had higher YG $(P<$ $0.05)$ than those fed the high-corn, $20 \%$ fresh wet distillers grains, $40 \%$ stored wet distillers grains without hay, and corn gluten feed (wet or dried) diets. The lowest value (2.70) was for steers fed $40 \%$ wet corn gluten feed.

Rates of Ultrasound Backfat and Marbling Deposition. The rates of ultrasound backfat thick- ness and marbling deposition are the slopes obtained from simple linear regression analysis (Table 5). Bruns et al. (2004) reported that in a similar population of calf-fed steers, marbling score $(\mathbf{M b S})$ and, to a large degree, backfat thickness increased linearly when analyzed as a component of growth over time. Steers offered the high-corn diet had the slowest rate of backfat deposition $(P<0.05)$. Steers fed dried distillers grains, wet distillers grains, or corn gluten feed deposited approximately $0.02 \mathrm{~mm} / \mathrm{d}$ more backfat than steers fed the high-corn diet. However, no difference $(P>0.05)$ was detected in the rates of backfat deposition between steers fed the high-corn diet and those fed the $40 \%$ dried corn gluten feed diet. In addition, steers consuming $40 \%$ dried distillers grains had the greatest rate of backfat deposition $(0.085$ $\mathrm{mm} / \mathrm{d}$ ); however, this was significant $(P<0.05)$ only when compared with steers fed $40 \%$ fresh wet distillers grains and all the diets with $40 \%$ corn gluten feed (wet or dried). As expected, steers with the greatest rate of ultrasound backfat deposition had the greatest carcass backfat thickness.

The rate of ultrasound marbling was expressed 1/100 MbS units per day. Steers fed the different diets ranged from 0.89 to 1.23 (1/100 MbS units per day). This narrow range can explain the similar $\operatorname{MbS}(P=0.15)$ given to the carcasses. The greatest rate of intramuscular fat deposition was observed in steers fed $40 \%$ DDGS, which also had the greatest rate of backfat deposition. This was significant $(P<0.05)$ when compared with the rates of steers in the other dietary treatments, with the exception of steers fed diets containing $40 \%$ stored wet distillers grains, $40 \%$ wet corn gluten feed, and $40 \%$ dried corn gluten feed. Furthermore, the rate of backfat deposition for steers fed the high-corn diet was less $(P<0.05)$ than the rates for steers consuming the other diets. However, no differences $(P>0.05)$ were detected when 

Table 5 . Effect of dietary treatment on the intercept (I) and rate (R) of ultrasound backfat, marbling, and
marbling over backfat deposition of feedlot steers

\begin{tabular}{|c|c|c|c|c|c|c|c|}
\hline \multirow[b]{2}{*}{ Item } & \multicolumn{2}{|c|}{ Backfat } & \multicolumn{2}{|c|}{ Marbling } & \multicolumn{3}{|c|}{ Marbling/backfat } \\
\hline & $\mathrm{I}, \mathrm{mm}$ & $\mathrm{R}, \mathrm{mm} / \mathrm{d}$ & I, score ${ }^{1}$ & $\begin{array}{c}\mathrm{R}, 1 / 100 \\
\text { marbling score } \\
\text { units per day }\end{array}$ & I & $\begin{array}{c}\mathrm{R}, 100 \\
\text { marbling score } \\
\text { units/cm backfat }\end{array}$ & $\mathbf{N}$ \\
\hline \multicolumn{8}{|c|}{ Dietary treatment ${ }^{2}$} \\
\hline $\mathrm{Cn}$ & 5.056 & $0.0591^{*}$ & 386 & $0.89^{*}$ & 318 & 190 & 126 \\
\hline $50 \mathrm{C}$ & 5.461 & $0.071^{*}$ & 389 & $0.96^{*}$ & 317 & 183 & 139 \\
\hline $40 D G$ & 5.314 & 0.085 & 386 & 1.23 & 305 & 210 & 139 \\
\hline 40WD & 5.169 & $0.073^{*}$ & 387 & $1.00^{*}$ & 318 & 174 & 134 \\
\hline 40WC & 5.282 & $0.070^{*}$ & 388 & $1.03^{*}$ & 287 & 240 & 119 \\
\hline 40SD & 5.268 & 0.081 & 391 & 1.05 & 332 & 153 & 127 \\
\hline 20WD & 6.075 & 0.079 & 388 & $0.95^{*}$ & 321 & 189 & 49 \\
\hline 40DG/C & 5.339 & 0.075 & 383 & $0.87^{*}$ & 335 & 177 & 54 \\
\hline 40DG/H & 5.142 & 0.082 & 389 & $1.02^{*}$ & 332 & 138 & 120 \\
\hline 40WCG & 5.341 & $0.072^{*}$ & 395 & 1.06 & 288 & 244 & 110 \\
\hline 20WD/WCG & 5.242 & 0.084 & 408 & 1.16 & 306 & 245 & 70 \\
\hline 40DCGF & 4.883 & $0.070^{*}$ & 390 & $0.95^{*}$ & 290 & 246 & 97 \\
\hline$P$-value & 0.72 & $<0.01$ & 0.53 & 0.02 & 0.39 & 0.30 & - \\
\hline SEM & 1.839 & 0.032 & 20 & 0.16 & 15 & 60 & - \\
\hline
\end{tabular}

${ }^{1}$ University of Illinois marbling score: $500=$ Small $^{0}, 600=$ Modest $^{0}$.

${ }^{2} \mathrm{Cn}=75 \%$ dry-rolled corn; $50 \mathrm{C}=50 \%$ dry-rolled corn; 40DG $=40 \%$ dry distillers grains; $40 \mathrm{WD}=40 \%$ fresh wet distillers grains; 40WC $=40 \%$ fresh wet corn gluten feed; $40 \mathrm{SD}=40 \%$ stored wet distiller grains; $20 \mathrm{WD}=20 \%$ wet distillers grains $+20 \%$ wet corn gluten feed; $40 \mathrm{DG} / \mathrm{C}=40 \%$ stored wet distillers grains $+7 \%$ dry-rolled corn; $40 \mathrm{DG} / \mathrm{H}=40 \%$ stored wet distillers grains $+7.5 \%$ hay; $40 \mathrm{WCG}=40 \%$ wet corn gluten feed; $20 \mathrm{WD} / \mathrm{WCG}=20 \%$ fresh wet distillers grains $+20 \%$ wet corn gluten feed; $40 \mathrm{DCGF}=40 \%$ dried corn gluten feed.

*Significant differences $(P<0.05)$ when compared with the highest value within the same measurement.

compared with the rates of steers fed $40 \%$ DDGS and $40 \%$ stored wet distillers grains. Dietary factors that have been proposed to affect MbS include providing lipids in the diet; different methods of processing grain, resulting in differing amounts of starch escaping rumen digestion; and differing levels of amino acid supply relative to energy. Oddy et al. (2000) concluded that grain-based diets containing different amounts of protein relative to estimated requirements had no significant effect on the rate of fattening (fat thickness) or on intramuscular fat content. However, there was a trend for steers fed high-protein diets to produce less marbling and for those fed low-protein diets to produce more marbling compared with control steers. In contrast, Vander Pol et al. (2006b) reported no significant differences for any carcass characteristic in yearlings fed wet distillers grains compared with a corn control diet.
In this study, the amount of ultrasound marbling deposited per centimeter of backfat thickness was not affected $(P=0.303)$ by dietary treatment. Steers averaged about $200 \mathrm{MbS}$ units/cm of backfat thickness deposited. The dietary factors controlling adipose tissue growth are not completely understood and likely differ between subcutaneous and intramuscular fat depots. Ruminants fed grain-based diets have a greater concentration of propionate than those fed a foragebased diet (Owens and Goetsch, 1988; Okine and Arthur, 1997). Increasing propionate, a gluconeogenic precursor, may lead to greater glucose availability and hence greater marbling deposition. However, in this experiment, cattle fed the greatest amount of grain were intermediate in the rate of marbling per centimeter of backfat thickness. Research by Vander Pol et al. (2006a) revealed a higher energy value of feeding distillers by-products compared with dry-rolled corn. In addition, Ham et al. (1994) reported an increase in propionate concentrations when $20 \%$ thin stillage was infused or when $15 \%$ condensed distillers solubles was fed to finishing steers. The authors suggest that an alteration of microbial populations, specifically a reduction of the protozoa populations, may have caused the increased propionate.

\section{Breed of Sire Effect}

Performance. Four breed compositions were represented within the progeny of 65 sires identified in the data set. There were 11 Angus sires with 241 progeny, 32 Simmental sires with 599 progeny, 18 SA sires with 296 progeny, and four $75 \mathrm{~S}$ sires with 120 progeny.

Initial $\mathrm{BW}$ and adjusted final $\mathrm{BW}$ did not differ $(P=0.2498$ and $P=$ 0.2448; Table 6) among the breeds of 
Table 6. Effect of breed of sire on performance and carcass characteristics and intercept and rate of ultrasound backfat, marbling, and marbling over backfat deposition of feedlot steers

\begin{tabular}{|c|c|c|c|c|c|c|}
\hline \multirow[b]{2}{*}{ Item } & \multicolumn{4}{|c|}{ Breed of sire } & \multirow[b]{2}{*}{ SEM } & \multirow[b]{2}{*}{$P$-value } \\
\hline & Angus & Simmental & $\begin{array}{c}\text { Simmental- } \\
\text { Angus }\end{array}$ & $75 \%$ Simmental & & \\
\hline $\mathrm{N}$ & 241 & 599 & 296 & 120 & & \\
\hline \multicolumn{7}{|l|}{ Performance characteristic } \\
\hline Initial BW, kg & 329 & 336 & 331 & 339 & 2 & 0.25 \\
\hline Adjusted final BW, ${ }^{1} \mathrm{~kg}$ & 588 & 598 & 593 & 605 & 8 & 0.24 \\
\hline Average daily DMI, $\mathrm{kg}$ & $10.61^{a}$ & $10.31^{b}$ & $10.33^{b}$ & $10.47^{\mathrm{ab}}$ & 0.32 & 0.03 \\
\hline $\mathrm{ADG}, \mathrm{kg}$ & 1.56 & 1.57 & 1.58 & 1.60 & 0.05 & 0.94 \\
\hline $\mathrm{G}: \mathrm{F}$ & 0.150 & 0.155 & 0.155 & 0.155 & 0.0077 & 0.27 \\
\hline \multicolumn{7}{|l|}{ Carcass characteristic } \\
\hline Hot carcass weight, $\mathrm{kg}$ & 378 & 383 & 381 & 388 & 5 & 0.44 \\
\hline Backfat, cm & $1.4^{\mathrm{a}}$ & $1.21^{\mathrm{d}}$ & $1.29^{b c}$ & $1.25^{\mathrm{cd}}$ & 0.07 & 0.01 \\
\hline Marbling score ${ }^{2}$ & $584^{a}$ & $543^{c}$ & $568^{\mathrm{b}}$ & $543^{c}$ & 11 & 0.01 \\
\hline Ribeye area, $\mathrm{cm}^{2}$ & $87.69^{b}$ & $91.93^{\mathrm{a}}$ & $92.31^{\mathrm{a}}$ & $91.87^{\mathrm{a}}$ & 2.61 & 0.01 \\
\hline $\mathrm{KPH}, \%$ & 2.27 & 2.22 & 2.27 & 2.31 & 0.13 & 0.81 \\
\hline Calculated YG & $3.31^{\mathrm{a}}$ & $2.77^{b}$ & $2.83^{b}$ & $2.88^{b}$ & 0.05 & 0.01 \\
\hline \multicolumn{7}{|l|}{ Intercept and rate of ultrasonic measurement } \\
\hline Backfat intercept, mm & 5.74 & 5.28 & 5.60 & 5.15 & 1.69 & 0.08 \\
\hline Backfat rate, $\mathrm{mm} / \mathrm{d}$ & $0.091^{a}$ & $0.067^{c}$ & $0.073^{b}$ & $0.075^{b}$ & 0.032 & $<0.01$ \\
\hline Marbling intercept, marbling score & 404 & 390 & 388 & 400 & 19.07 & 0.01 \\
\hline Marbling rate, $1 / 100$ marbling score units per day & $1.16^{a}$ & $0.91^{b}$ & $1.14^{a}$ & $0.93^{b}$ & 0.14 & 0.03 \\
\hline Marbling/backfat intercept & 317 & 323 & 297 & 345 & 16.48 & 0.01 \\
\hline $\begin{array}{l}\text { Marbling/backfat rate, } 100 \text { marbling score units/cm } \\
\text { backfat }\end{array}$ & 207 & 182 & 231 & 163 & 71 & 0.69 \\
\hline
\end{tabular}

${ }^{\mathrm{a}-\mathrm{d}}$ Superscripts with different letters differ $(P \leq 0.05)$.

${ }^{1}$ Calculated from adjusted hot carcass weight divided by a pooled dressing percentage.

${ }^{2}$ University of Illinois marbling score: $500=$ Small $^{0}, 600=$ Modest $^{0}$.

sire. In disagreement with our finding, previous research (Cundiff et al., 1993) has shown a higher growth rate, mature size, and lean-to-fat ratio for progeny from Simmental sires compared with those from Angus sires. For DMI, a difference $(P=0.0338)$ was detected among the breeds of sire. Steers sired by Angus bulls had greater $(P<0.05)$ DMI than the progeny of Simmental or SA sires. Angus-sired steers had approximately $0.3 \mathrm{~kg}$ more DMI per day. However, no significant differences were detected when compared with steers sired by $75 \mathrm{~S}$ bulls; we attribute this result to the fact that only 4 sires were represented in the analysis. All progeny from Simmental and Simmental crossbred sires had similar DMI $(P$ $>0.05)$. The ADG for all steers from the different breeds of sire did not differ $(P=0.9449)$. On average, steers gained $1.57 \mathrm{~kg} / \mathrm{d}$. Feed efficiency, expressed as G:F, was similar $(P=$ $0.2745)$ across the progeny of Simmental and Simmental crossbred sires. Steers had an average G:F of 0.154 . Smith et al. (1976) first reported that Simmental crossbred steers were the largest and fastest growing breed group when compared with other crossbred steers, including the Angus breed. In a more recent study, Field and Taylor (2003) stated that Hereford and Angus breeds ranked first and second, respectively, in feed efficiency when 9 breeds were compared for BW gain efficiency at endpoints of Small marbling. In the current study, steers represented various degrees of heterosis, which could have had an effect on growth traits such as feed efficiency.

Some evidence exists that the expression of genetic improvement through selection, heterosis, maternal effects, and direct genetic effects may not be the same in different production environments (Barlow, 1981; Holloway et al., 1992; Brown et al., 1993). Year and breed resulted in a significant interaction $(P<0.05)$ for DMI, initial BW, and G:F. In agreement with our findings, Brown et al., (1993) reported that for the postweaning trait of 205-d shrunk BW, dam breed, sire breed $\times$ dam breed, and environment effects were significant $(P<0.05)$ and that there was a trend for the maternal advantage of the Angus breed. Furthermore, Mulder and Bijma (2005) concluded that the genotype $\times$ environment interaction between selection environment and production environment decreased genetic BW gain under commercial conditions. 
Carcass. The carcass characteristics for all the sire breed groups differed $(P<0.05$; Table 6$)$, with the exception of HCW and percentage of KPH. Carcass backfat thickness was greater $(P<0.05)$ for the progeny of Angus bulls than the progeny of Simmental, SA, and 75S sires. Steers from Angus sires had approximately $0.15 \mathrm{~cm}$ greater backfat thickness. No differences $(P>0.05)$ were detected among the progeny of Simmental, $75 \mathrm{~S}$, and SA. However, steers sired by SA bulls had significantly greater backfat thickness than steers sired by Simmental bulls. In agreement with our findings, Ríos-Utrera et al. (2006) reported absolute differences in $\mathrm{HCW}$ of steers sired by Simmental bulls when compared with Angus progeny. Furthermore, carcass backfat thickness was significantly greater in steers sired by Angus bulls. Other studies (Smith et al., 1976; Cundiff et al., 1993; Marshall, 1994) have also shown results for carcass characteristics similar to the ones reported for this experiment.

On average, carcasses had an MbS of 559. Steers sired by Angus bulls had a higher $(P<0.05)$ MbS than steers sired by Simmental, SA, and $75 \mathrm{~S}$ bulls. However, all breed groups averaged either low or average Choice.

Progeny from Angus sires averaged 3.31 CYG, which was higher $(P<$ 0.05) than the CYG of progeny from Simmental, SA, and 75S sires. Greiner (2002) reported that British breeds produced progeny that were $88 \%$ Choice or higher and $22.3 \%$ were YG 1 and 2 compared with Continental breeds, which graded $60.9 \%$ Choice or higher and with $57 \%$ of progeny having YG 1 and 2 carcasses. On average, steers sired from Simmental, SA, and $75 \mathrm{~S}$ had REA of $92.03 \mathrm{~cm}^{2}$. Steers from the previous sire breeds differed $(P<0.05)$ when compared with REA of Angus sires, whose REA was $4 \mathrm{~cm}^{2}$ smaller. These data confirm the complementarity of Simmental sires bred to Angus cows. Marshall (1994) proposed that although carcass heterosis effects do not seem to improve carcass composition, crossbreeding could potentially benefit carcass composi- tion through complementary blending of breed characteristics. In addition, Cundiff et al. (1993) concluded that genetic variation found between breeds is comparable in magnitude to that found within breeds for growth for most carcass and meat traits. Thus, significant genetic change can result from selection both between and within breeds.

An interaction for sire breed $x$ dietary treatment $(P=0.0003)$ was observed for the percentage of $\mathrm{KPH}$. No other significant interaction was observed for carcass characteristics. In agreement with our findings, Ferrell and Jenkins (1998) reported that sire breed influenced $(P<0.02)$ hide, stomach complex, heart, and spleen weights and tended $(P<0.10)$ to influence lung and kidney weights. Furthermore, few interactions were noted, indicating that the response of these organs or tissues to the imposed treatments was similar among sire or dam breeds.

Rates of Backfat and Marbling Deposition for Breed of Sire and Individual Sire Effect. Four breed compositions were included in the regression analysis to obtain ultrasound rates of backfat thickness, marbling, and marbling over backfat deposition (Table 6). For the rate of backfat thickness, the greatest rate $(P<$ $0.05)$ was observed in the progeny of Angus sires. Field and Taylor (2003) showed the greatest relative differences in lean-to-fat ratio between the Simmental and Angus breeds. Angussired steers were depositing $0.019 \mathrm{~mm}$ more backfat daily than steers sired by Simmental, SA, and 75S sires. This represents a difference of approximately $20 \%$ in daily backfat deposition. In this experiment, progeny of SA and 75 S sires were similar $(P>$ $0.05)$ and were depositing on average $0.074 \mathrm{~mm}$ of backfat thickness daily. Progeny from Simmental sires had the least $(P<0.05)$ rate of deposition. Similarly, Cundiff et al. (1993) reported from the breed comparisons in the germplasm evaluation program at the Meat Animal Research Center (Clay Center, NE) that Simmental-sired steers had the least backfat thickness.
Bergen et al. (2006) stated that little is known about the genetic control of carcass fat partitioning despite its potential importance in beef cattle breeding programs. If genetic relationships among the different fat depots are not highly correlated, selection for increased carcass leanness does not necessitate a reduction in MbS. An earlier study (Koch et al., 1982) reported that genetic correlations among fat thickness and marbling were -0.1 and -0.14 , respectively. In addition, the authors concluded that genetic increases in growth rate favored the growth of lean tissue relative to fat.

The rate of ultrasound intramuscular fat or marbling deposition ranged from 0.91 to 1.16 (1/100 units per day) for the sire groups. Steers sired by Angus and SA bulls had the greatest rates $(P<0.05)$ of marbling deposition. Their progeny, on average, had a daily deposition of intramuscular fat of 0.23 (1/100 units) more than progeny of Simmental and $75 \mathrm{~S}$ bulls. No differences $(P>0.05)$ were detected between the rates of steers sired by Simmental and 75S. Angus are recognized as the breed with the greatest marbling potential, but with only 11 sires tested, it may not be totally representative of the breed. In agreement, Sapp et al., (2002) concluded that yearling Angus bulls selected for high phenotypic ultrasound intramuscular fat percentage or phenotypic ultrasound intramuscular fat percentage EPD can be expected to produce steers with significantly greater amounts of marbling and higher QG. Gwartney et al. (1996) reported significantly more marbling in carcasses from a group of high-marbling EPD steers compared with those from a low-marbling EPD group. In that experiment, individual EPD were not calculated.

Each breed composition is different in its dynamics of intramuscular and backfat deposition. When the change in marbling per centimeter of backfat thickness was analyzed, no differences $(P=0.6950)$ were detected among the breeds of sire. On average, the rate of marbling over backfat thick- 
ness was $184 \mathrm{MbS}$ units for $1 \mathrm{~cm}$ of backfat thickness. Beef cattle are often fed to a level of external fat that provides a reasonable chance to achieve a low Choice MbS and a desirable dressing percentage. Previous literature indicates that the genetic correlation of $\mathrm{MbS}$ and fat thickness or live growth traits is low (Vieselmeyer et al., 1996). Therefore, selection of sires with high rates of marbling deposition relative to backfat thickness may result in progeny with lower amounts of subcutaneous and seam fat at a constant marbling endpoint or more marbling at a constant fat thickness or carcass weight (Gwartney et al., 1996).

\section{IMPLICATIONS}

Considering the projected increase in the availability of distillers byproducts in the United States, beef cattle producers can use these products in the finishing diets of feedlot steers to enhance performance and maintain desirable carcass quality and retail yield. This study indicates an improvement in live performance and no negative effects on carcass quality when finishing steers are fed different distillers co-products (i.e., fresh wet, stored wet, and dried distillers grains). Steers sired by Simmental or crossbred Simmental bulls had the greatest feed efficiency; however, no significant differences were detected in their daily growth rate. The progeny of Angus bulls had the greatest rate of backfat deposition, which explains the greatest amount of carcass backfat thickness. Although MbS were higher in steers sired by Angus bulls, the rate of marbling was similar to that for the progeny of SA bulls. Overall, Angus and SA sires had the greatest deposition of intramuscular fat at a constant backfat thickness endpoint of $1 \mathrm{~cm}$. These differences may be attributed to the genetic potential of some sires to deposit more intramuscular fat, with small increases in subcutaneous fat. These data suggest that it may be possible to select sires that have a greater rate of marbling per centimeter of backfat deposition and thus improve both QG and YG. Future research is needed to better understand these variations in MbS and backfat deposition in a population of known sires.

\section{LITERATURE CITED}

Al-Suwaiegh, S., K. C. Fanning, R. J Grant, C. T. Milton, and T. J. Klopfenstein. 2002. Utilization of distiller's grains from the fermentation of sorghum or corn in diets for finishing beef and lactating dairy cattle. J. Anim. Sci. 80:1105.

Barlow, R. 1981. Experimental evidence for the interaction between heterosis and environment in animals. Anim. Breed. Abstr. 49:715.

Bergen, R., S. P. Miller, J. W. Wilton, and I. B. Mandell. 2006. Genetic correlations between live yearling bull and steer carcass traits adjusted to different slaughter end points. 2. Carcass fat partitioning. J. Anim. Sci. 84:558.

Brethour, J. R. 1994. Estimating marbling score in live cattle from ultrasound images using pattern recognition and neural network procedures. J. Anim. Sci. 72:1425.

Brown, M. A., A. H. Brown Jr., W. G. Jackson, and J. R. Miesner. 1993. Genotype $\times$ environment interactions in postweaning performance to yearling in Angus, Brahman, and reciprocal-cross calves. J. Anim. Sci. 71:3273.

Bruns, K. W., R. H. Pritchard, and D. L. Boggs. 2004. The relationships among body weight, body composition, and intramuscular fat content in steers. J. Anim. Sci. 82:1315.

Consortium. 1988. Guide for the Care and Use of Agricultural Animals in Agricultural Research and Teaching. Consortium for Developing a Guide for the Care and Use of Agricultural Animals in Agricultural Research and Teaching, Savoy, IL.

Cundiff, L. V., F. Szabo, K. E. Gregory, R. M. Koch, M. E. Dikeman, and J. D. Crouse. 1993. Breed comparisons in the germplasm evaluation program at MARC. p. 13 in Beef Improve. Fed. 25th Anniv. Conf., Asheville, NC.

Ferrell, C. L., and T. G. Jenkins. 1998. Body composition and energy utilization by steers of diverse genotypes fed a high-concentrate diet during the finishing period: I. Angus, Belgian Blue, Hereford, and Piedmontese sires. J. Anim. Sci. 76:637.

Field, T. G., and R. E. Taylor. 2003. Beef Production Management and Decisions. 4th ed. Prentice Hall, Upper Saddle River, NJ.

Greiner, S. P. 2002. Crossbreeding Beef Cattle. Publ. 400-805. Virginia Coop. Ext., Virginia Polytechnic Inst. and State Univ., Blacksburg.
Gwartney, B. L., C. R. Calkins, R. J. Rasby, R. A. Stock, B. A. Vieselmeyer, and J. A. Gosey. 1996. Use of expected progeny differences for marbling in beef: II. Carcass and palatability traits. J. Anim. Sci. 74:1014.

Ham, G. A., R. A. Stock, T. J. Klopfenstein, E. M. Larson, D. H. Shain, and R. P. Huffman. 1994. Wet corn distillers by-products compared with dried corn distillers grains with solubles as a source of protein and energy for ruminants. J. Anim. Sci. 72:3246.

Holloway, J. W., B. G. Warrington, F. M. Rouquette Jr., C. R. Long, M. K. Owens, and J. F. Baker. 1992. Forage availability $\times$ heifer phenotype interactions for Brahman-Hereford $\mathrm{F}_{1}$ yearling heifers grazing humid pasture and semiarid rangeland. J. Anim. Sci. 70:2658.

Koch, R. M., L. V. Cundiff, and K. E. Gregory. 1982. Heritabilities and genetic, environmental and phenotypic correlations of carcass traits in a population of diverse biological types and their implications in selection programs. J. Anim. Sci. 55:1319.

Larson, E. M., R. A. Stock, T. J. Klopfenstein, M. H. Sindt, and R. P. Huffman. 1993. Feeding value of wet distillers by-products for finishing ruminants. J. Anim. Sci. 71:2228.

Leibovich, J., J. T. Vasconcelos, and M. L. Galyean. 2009. Effects of corn processing method in diets containing sorghum wet distillers grain plus solubles on performance and carcass characteristics of finishing beef cattle and on in vitro fermentation of diets. J. Anim. Sci. 87:2124.

Lodge, S. L., R. A. Stock, T. J. Klopfenstein, D. H. Shain, and D. W. Herold. 1997. Evaluation of corn and sorghum distillers by-products. J. Anim. Sci. 75:37.

Loy, T. W., J. C. MacDonald, T. J. Klopfenstein, and G. E. Erickson. 2007. Effect of distillers grains or corn supplementation frequency on forage intake and digestibility. J. Anim. Sci. 85:2625.

Loza, P. L., K. J. Vander Pol, G. E. Erickson, T. J. Klopfenstein, and R. A. Stock. 2005. Effect of feeding a by-product combination consisting of wet distillers grains and wet corn gluten feed to feedlot cattle. Beef Cattle Rep. Univ. Nebraska, Lincoln.

Mader, T. L. 2003. Environmental stress in confined beef cattle. J. Anim. Sci. 81:E110.

Marshall, D. M. 1994. Breed differences and genetic parameters for body composition traits in beef cattle. J. Anim. Sci. 72:2745.

Mulder, H. A., and P. Bijma. 2005. Effects of genotype $\times$ environment interaction on genetic gain in breeding programs. J. Anim. Sci. 83:49.

NRC. 1996. Nutrient Requirements of Beef Cattle. 7th rev. ed. Natl. Acad. Press, Washington, DC.

Oddy, H., C. Smith, R. Dobos, G. Harper, and P. Allingham. 2000. Effect of dietary protein content on marbling and performance 
of feedlot cattle. Final Rep. Project FLOT 210. Meat and Livestock Australia, Armidale, New South Wales, Australia.

Okine, E. K., and P. F. Arthur. 1997. Does the amount and rate of fatty acid deposition in ruminants depend on the type of diet or energy level of the diet? http://www.agric. gov.ab.ca/reseach/researhupdate/97beef 28 . html Accessed March 20, 2007.

Owens, F. N., and A. L. Goetsch. 1988. Rumen fermentation. p. 145 in The Ruminant Animal-Digestive Physiology and Nutrition. D. C. Church, ed. Waveland Press Inc., Prospect Heights, IL.

Ríos-Utrera, A., L. V. Cundiff, K. E. Gregory, R. M. Koch, M. E. Dikeman, M. Koohmaraie, and L. D. Van Vleck. 2006. Effects of age, weight, and fat slaughter end points on estimates of breed and retained heterosis effects for carcass traits. J. Anim. Sci. 84:63.

Sapp, R. L., J. K. Bertrand, T. D. Pringle, and D. E. Wilson. 2002. Effects of selection for ultrasound fat percentage in Angus bulls on carcass traits of progeny. J. Anim. Sci. 80:2017.

SAS Institute. 2003. SAS/STAT User's Guide. SAS Inst. Inc., Cary, NC.

Sherman, G. B., S. D. Kachman, L. L. Hungerford, G. P. Rupp, C. P. Fox, M. D. Brown, B. M. Feuz, and T. R. Holm. 2004. Impact of candidate sire number and sire relatedness on DNA polymorphism-based measures of exclusion probability and probability of unambiguous parentage. Anim. Genet. 35:220.

Slate, J., T. C. Marshall, and J. M. Pemberton. 2000. A retrospective assessment of the accuracy of the paternity inference program CERVUS. Mol. Ecol. 9:801.

Smith, G. M., D. B. Laster, L. V. Cundiff, and K. E. Gregory. 1976. Characterization of biological types of cattle II. Postweaning growth and feed efficiency of steers. J. Anim. Sci. 43:37.
Taylor, R. E. 1994. The marketing system. p. 481 in Beef Production and Management Decisions. 2nd ed. MacMillan Publ. Co., New York, NY.

VanderPol, K., G. Erickson, M. Greenquist, T. Klopfenstein, and T. Robb. 2006a. Effect of corn processing in finishing diets containing wet distillers grains on feedlot performance and carcass characteristics of finishing steers. Beef Cattle Rep. Univ. Nebraska, Lincoln.

VanderPol, K., G. Erickson, T. Klopfenstein, M. Greenquist, and T. Robb. 2006b. Effect of dietary inclusion of wet distillers grains on feedlot performance of finishing cattle and energy relative to corn. Beef Cattle Rep. Univ. Nebraska, Lincoln.

Vieselmeyer, B. A., R. J. Rasby, B. L. Gwartney, C. R. Calkins, R. A. Stock, and J. A. Gosey. 1996. Use of expected progeny differences for marbling in beef: I. Production traits. J. Anim. Sci. 74:1009. 